\title{
Assessment of morphometric characteristics of Chakrar watershed in Madhya Pradesh India using geospatial technique
}

\author{
Sandeep Soni ${ }^{1}$
}

Received: 16 May 2015/Accepted: 16 February 2016/Published online: 29 February 2016

(c) The Author(s) 2016. This article is published with open access at Springerlink.com

\begin{abstract}
The quantitative analysis of the watershed is important for the quantification of the channel network and to understand its geo-hydrological behaviour. Assessment of drainage network and their relative parameters have been quantitatively carried out for the Chakrar watershed of Madhya Pradesh, India, to understand the prevailing geological variation, topographic information and structural setup of the watershed and their interrelationship. Remote Sensing and Geographical Information System (GIS) has been used for the delineation and calculation of the morphometric parameters of the watershed. The Chakrar watershed is sprawled over an area of $415 \mathrm{~km}^{2}$ with dendritic, parallel and trellis drainage pattern. It is sub-divided into nine sub-watersheds. The study area is designated as sixth-order basin and lower and middle order streams mostly dominate the basin with the drainage density value of $2.46 \mathrm{~km} / \mathrm{km}^{2}$ which exhibits gentle to steep slope terrain, medium dense vegetation, and less permeable with medium precipitation. The mean bifurcation value of the basin is 4.16 and value of nine sub-watersheds varies from 2.83 to 4.44 which reveals drainage networks formed on homogeneous rocks when the influences of geologic structures on the stream network is negligible. Form factor, circularity ratio and elongation ratio indicate an elongated basin shape having less prone to flood, lower erosion and sediment transport capacities. The results from the morphometric assessment of the watershed are important in water resources evaluation and its management and for the
\end{abstract}

Sandeep Soni

sandeepsoni80@gmail.com

1 Remote Sensing and GIS Lab, MGCGV, Chitrakoot, Satna, MP, India selection of recharge structure in the area for future water management.

Keywords Chakrar watershed and sub-watersheds · GIS · Morphometry · River basin

\section{Introduction}

River basins (the land area between the source and the mouth of a river including all of the lands that drain into the river) influenced by catchment discharges are important geographical units for water resource management. Rapid and unsustainable development in the river basins has led to the disruption of natural hydrological cycles. In many cases this has resulted in greater frequency and severity of flooding, drought and pollution. The degradation and loss of biodiversity impose major economic and social losses and costs to the human populations of these river basins. Water demand for drinking and other purposes is increasing day by day due to urbanization and population growth, that has led to increasing water crisis affecting surface and ground water (Thakur et al. 2011; Singh et al. 2011; Diwakar and Thakur 2012). So, evaluation of water resources is urgently required for livelihood sustainability and economy (Singh et al. 2013). Development and management plans are also required for ecosystem to survive and continue to provide essential goods and services for local communities. Optimum and sustainable utilization of fresh water resources is also needed in new approaches of water and basin management.

In watershed management plans, the knowledge of hydrological nature of the rocks within the watershed is necessary that can be obtained through quantitative morphometric analysis of the watershed (Singh et al. 2014). In 
a watershed, basic unit is stream network which reveals structural, geological and hydrological setup of the watershed. The knowledge of topography, stream network and its pattern, geological and geomorphological setup in the watershed is requisite for its management and implementation plan for conservation measures (Sreedevi et al. 2013). Various hydrological problems of ungauged watershed are solved by different regional hydrological models which are developed using geomorphological characteristics of the watershed. According to Esper (2008), morphometric characterization of a watershed is important to evaluate hydrological setup coupled with geomorphology and geology.

Drainage basins, catchments and sub-catchments are the fundamental units for the management of land and water resources (Moore et al. 1994). Morphometric analysis in a drainage basin is important for hydrological investigation and development and management of drainage basin (Rekha et al. 2011). Morphometric parameters and climatic conditions are the key determinants of running water ecosystems functioning at the basin scale (Lotspeich and Platts 1982; Frissel et al. 1986). The quantitative analysis of morphometric parameters is found to have immense utility in river basin evaluation, watershed prioritization for soil and water conservation and natural resource management at watershed level (Malik et al. 2011). The morphometric characteristics of the watershed control all surface runoff, and due to this condition, the watershed is considered an ideal territorial unit (Lima et al. 2011). Evaluation of morphometric parameters could be calculated from the analysis of various drainage parameters such as ordering of the various streams and basin area, perimeter and length of drainage channels, drainage density, stream frequency, bifurcation ratio, texture ratio, basin relief, ruggedness number, and time of concentration (Kumar et al. 2000; Nag and Chakraborthy 2003).

The basin morphometric parameters of the various catchments have been studied by many scientists using conventional (Horton 1945; Smith 1950; Strahler 1957) and remote sensing and GIS methods (Krishnamurthy and Srinivas 1995; Srivastava and Mitra 1995; Agarwal 1998; Biswas et al. 1999; Narendra and Nageswara Rao 2006). The fast emerging Geospatial technology (GT) viz. remote sensing, GIS, and GPS have been used as an effective tool to overcome most of the problems of land and water resources planning and management on the account of usage of conventional methods of data process (Tripathi et al. 2013; Soni et al. 2013; Banerjee et al. 2015). Geographical information system (GIS) technique is used for assessing various terrain and morphometric characteristics of drainage basin, as they provide a powerful tool for manipulation and analysis of spatial information particularly for the future identification and extraction of the information for better understanding (Vijith and Satheesh 2006). Main objective of the study is to elaborate morphometric characteristics of the Chakrar watershed and to identify basin geometry. Morphometric analysis is executed to understand the conservation measures and management of water resources for sustainable livelihood through Remote Sensing and GIS technique.

The Chakrar watershed is a tributary of the Narmada River. It rises towards south at an altitude of $1020 \mathrm{~m}$ of Satpura hills of Dindori district in Madhya Pradesh, India (Fig. 1) and flows to the north to meet the Narmada River. It is bounded by $22^{\circ} 31^{\prime} 12.24^{\prime \prime} \mathrm{N}-22^{\circ} 52^{\prime} 44.93^{\prime \prime} \mathrm{N}$ latitude and $81^{\circ} 14^{\prime} 41.23^{\prime \prime}$ E- $81^{\circ} 28^{\prime} 29.42^{\prime \prime}$ E longitude. Total catchment area of the watershed is $415 \mathrm{~km}^{2}$. It is an elongated river basin. The study region is characterized by high level plateau and half part by middle level plateau. In the study area, there is one common rock, i.e. basaltic lava flow of the Deccan Trap, made up principally of volcanic basic igneous rock. It is dark, hard and compact, fine grain, extrusive igneous rock, ejected as molten rock onto the Earth's surface solidifying quickly in the open air. Climatic characteristics of the study area is long hot summers, medium high monsoon rains and pleasantly cool winters. Such climate can be categorized under sub-continental type of sub-tropical monsoon climate. Long hot summers, heat respiting monsoon showers and cool winters provide a typical seasonality to this climatic reason. Long hot and dry summer season commences from March onwards, whence temperature starts increasing sharply and high temperature continues up to June. Average annual rainfall is 1200-1300 mm. The area has rich plant biodiversity wherein Sal (Shorea reobusta) is dominant species with associated species such as Buchanania lanzan, Bauhinia spp., Mallotus philipensis, Ougeinia oojeinesis, Terminalia chebula, Grewia spp., Gardenialatifolia, Anogeissus latifolia. The region also has some extremely valuable medicinal plants, which are now gravely endangered, like brahmi, gulbakawali, safedmusli, kalimusli, tejraj, bhojraj, patalkumhna, kali haldi, devraj, jatashankari, ashva gandha. There are some plants which are source of economy such as Tendu Patta, Mahlon patta, Harra-BaheraAmla and Achar chironzi. There are two major soil groups in the study region that is 'black cotton soil' and 'lateritic soil'. The black cotton soil is resultant of the volcanic eruption, mainly found in central alluvial plain and sloppy area while the lateritic soil is resultant of prolong erosion in the Deccan Trap, found in the hilly area of the Maikal range. In the 'kharif' season, Kodo-Kutki, Maize, Ramtil, Soybean and Paddy are mainly grown whereas during the 'rabi' season Wheat, Lentil and Mustard, Linseed, Pea and Gram are commonly grown. Agriculture, forest products, medicinal plants and some basalt mines are common source of income for the livelihood of local people. 


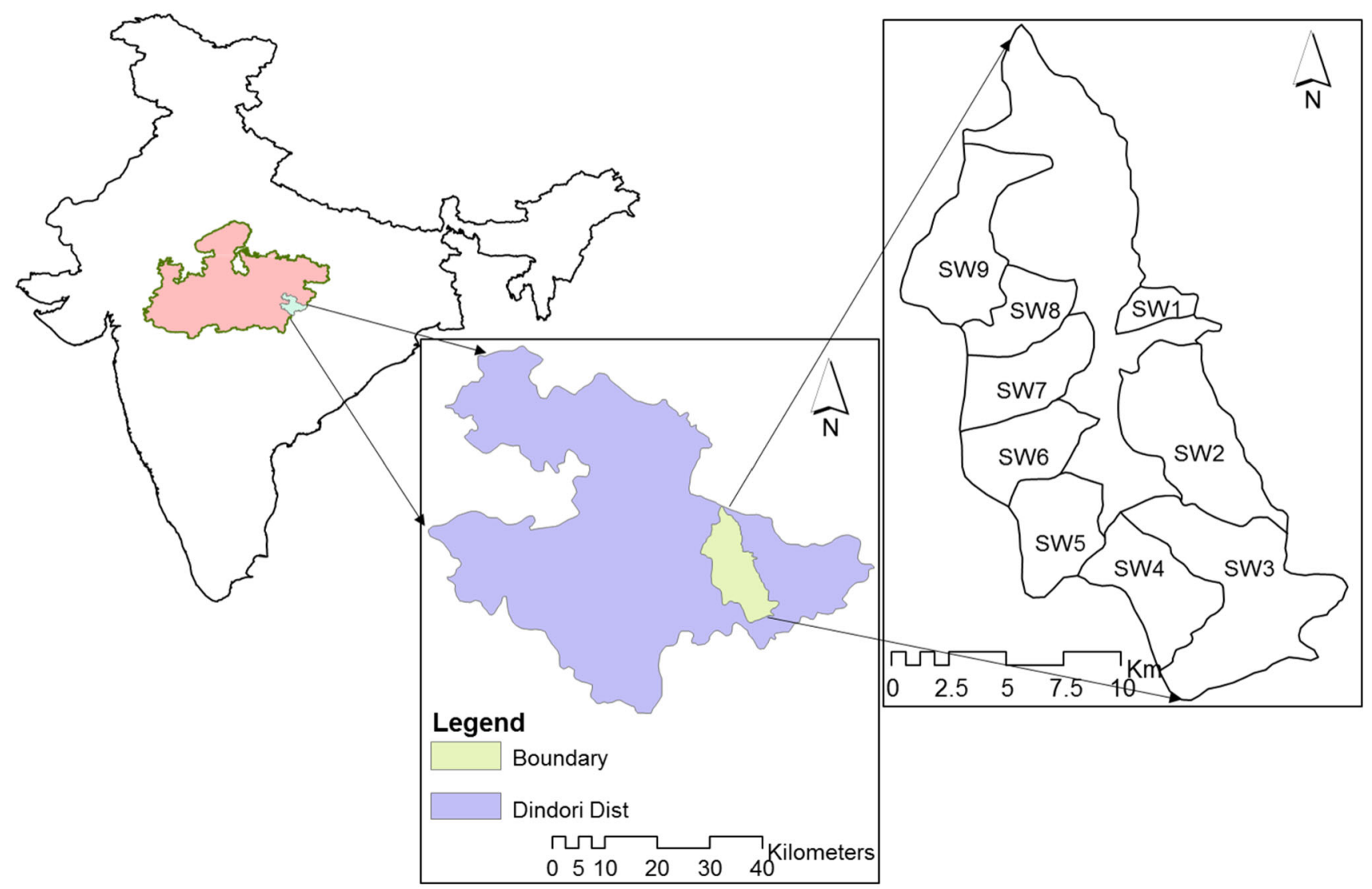

Fig. 1 Location map of Chakrar watershed

Agriculture depends on rainfall. Ground water condition and recharging is not very good due to its geological condition. So this study is necessary for watershed management and sustainability.

\section{Materials and methods}

Quantitative analysis of drainage basin reveals hydrogeological behaviour of drainage basin and describes nature of rocks, geomorphology and structure. The morphometric analysis also provides basin geometry, permeability nature of the rocks and its storage capacity. Delineation of the drainage basin and catchment area is the first step of the analysis. Survey of India (SOI) toposheet (scale 1:50,000) number $64 \mathrm{~F} / 2,64 \mathrm{~F} / 5$ and $64 \mathrm{~F} / 6$ were processed for basin stream and boundary delineation. Satellite-borne ASTER (Advanced Spaceborne Thermal Emission and Reflection, $30 \mathrm{~m}$ resolution, March 2011, Sheet no. ASTGTM2_N22E081) DEM (digital elevation model) was downloaded from http://earthexplorer.usgs.gov and Landsat TM satellite imagery (spatial resolution: $30 \mathrm{~m}$, October 2010, WRS-2, Path 143, Row 044) was downloaded from http://www.glovis.usgs.gov.in. Both the data was used to update basin streams and watershed boundary.
SOI toposheets were scanned and added in ERDAS Imagine 9.2 software for georeferencing and mosaic. Downloaded ASTER data and Landsat TM data was correlated with georeferenced toposheets and projected into same coordinate system (UTM WGS 84 Zone 44). Catchment area was delineated using aoi (area of interest) tool and updated with ASTER and Landsat data. This aoi layer was used to subset toposheets and space born data and converted into shape file as vector layer to treat as watershed boundary. Drainage network was digitized from toposheets and extracted from DEM using ArcGIS 9.3 software inside watershed boundary. Digitized stream network was updated with extracted stream network from DEM and with satellite data. These data were used to calculate linear aspect, areal aspect and relief aspect (Table 1) using ArcGIS 9.3 software.

\section{Results and discussion}

In morphometric analysis, configuration of the earth's surface and dimensions of the landforms is measured. This analysis is carried out for quantitative evaluation of drainage basin and for planning and management of water resources. Three major aspects: Linear, Areal and Relief 
Table 1 Methods for calculating morphometric parameters

\begin{tabular}{|c|c|c|c|}
\hline & Morphometric parameters & Methods & References \\
\hline \multirow[t]{6}{*}{ Linear aspects } & Stream order $(\mathrm{Nu})$ & Hierarchical ordering & Strahler (1957) \\
\hline & Stream length $(\mathrm{Lu})$ & Length of the stream & Horton (1945) \\
\hline & Mean stream length $(\mathrm{Lm})$ & $\mathrm{Lm}=\mathrm{Lu} / \mathrm{Nu}$ & Horton (1945) \\
\hline & Stream length ratio (Rl) & $\begin{array}{l}\mathrm{Rl}=\mathrm{Lu} / L(u-1), \text { where } \mathrm{Lu} \text { is stream length order } u \text { and } \\
L\left(u \_1\right) \text { is stream segment length of the next lower order }\end{array}$ & Horton (1945) \\
\hline & Bifurcation ratio $(\mathrm{Rb})$ & $\begin{array}{l}\mathrm{Rb}=\mathrm{Nu} / N(u-1), \text { where } \mathrm{Nu} \text { is number of streams of any } \\
\text { given order and } \mathrm{N}(u-1) \text { is number in the next higher } \\
\text { order }\end{array}$ & Horton (1945) \\
\hline & Rho coefficient $(\rho)$ & $\rho=\mathrm{Rl} / \mathrm{Rb}$ & Horton (1945) \\
\hline \multirow[t]{9}{*}{ Areal aspects } & Drainage density (Dd) & $\begin{array}{l}\mathrm{Dd}=\mathrm{L} / \mathrm{A} \text {, where } L \text { is total stream length, } A \text { is area of } \\
\text { watershed }\end{array}$ & Horton (1945) \\
\hline & Stream frequency $(\mathrm{Fs})$ & $\begin{array}{l}\text { Fs }=N / A \text {, where } N \text { is total number of streams and } A \text { is area } \\
\text { of watershed }\end{array}$ & Horton (1945) \\
\hline & Drainage texture (Dt) & $T=\mathrm{Dd} \times \mathrm{Fs}$ & Smith (1950) \\
\hline & Length of overland flow ( $\mathrm{Lg}$ ) & $\mathrm{Lg}=1 / 2 \mathrm{Dd}$ & Horton (1945) \\
\hline & Constant of channel maintenance $(C)$ & $C=1 / \mathrm{Dd}$ & Schumm (1956) \\
\hline & Form factor $(\mathrm{Ff})$ & $\mathrm{Ff}=A / \mathrm{Lb}^{2}$ & Horton (1945) \\
\hline & Circularity ratio $(\mathrm{Rc})$ & $\mathrm{Rc}=4 \pi A / P^{2}$ & Miller (1953) \\
\hline & Elongation ratio $(\mathrm{Re})$ & $\begin{array}{l}\mathrm{Re}=2 \sqrt{ }(A / \pi) / \mathrm{Lb} \text {, where } A \text { is area of watershed, } \pi \text { is } 3.14 \\
\text { and Lb is basin length }\end{array}$ & Schumm (1956) \\
\hline & Shape index (Sw) & $\mathrm{Sw}=1 / \mathrm{Ff}$ & Horton (1932) \\
\hline \multirow[t]{6}{*}{ Relief aspects } & Basin relief $(\mathrm{R})$ & $\begin{array}{l}\mathrm{R}=\mathrm{H}-\mathrm{h} \text {, where } H \text { is maximum elevation and } h \text { is } \\
\text { minimum elevation within the basin }\end{array}$ & Schumm (1956) \\
\hline & Relief ratio $(\mathrm{Rr})$ & $\mathrm{Rr}=R / \mathrm{Lb}$ & Schumm (1956) \\
\hline & Ruggedness number (Rn) & $\mathrm{Rn}=R \times \mathrm{Dd}$ & Strahler (1958) \\
\hline & Dissection index (Di) & $\mathrm{DI}=R / \mathrm{Ra}$, where $\mathrm{Ra}$ is absolute relief & Singh and Dubey (1994) \\
\hline & Gradient ratio $(\mathrm{Rg})$ & $\begin{array}{l}\mathrm{Rg}=\mathrm{Es}-\mathrm{Em} / \mathrm{Lb}, \text { where Es is the elevation at the source, } \\
\mathrm{Em} \text { is the elevation at the mouth }\end{array}$ & Sreedevi et al. (2009) \\
\hline & Melton ruggedness number (MRn) & $\mathrm{MRn}=H-h / A^{0.5}$ & Melton (1965) \\
\hline
\end{tabular}

have been described for analysis. Linear aspect in morphometry is characterized by basin length, stream order, stream number, stream length and bifurcation ratio. Areal aspect represents the characteristics of catchment area and describes how catchment area controls and regulates the hydrological behaviour. Relief aspect defines terrain setup of the catchment and terrain characteristics.

The morphometric parameters of the Chakrar watershed and its sub-watersheds have been examined and detailed in the following:

\section{Drainage pattern}

Drainage pattern may be expressed as a plan of a river system that reflects different types of information about geology and predominant slope of the drainage basin. The arrangement of streams in a drainage system constitutes the drainage pattern, which in turn reflects mainly structural or lithological controls of the underlying rocks. There are three types of drainage patterns are found i.e., dendritic, parallel and trellis (Fig. 2). Dendritic drainage pattern shows homogenous and uniform soil and rocks. Parallel drainage pattern indicates that the area has a gentle, uniform slope with less resistant bed rock. Whereas trellis type drainage pattern suggests down-turned folds called synclines form valleys.

\section{Linear aspects}

\section{Perimeter}

Overall perimeter of Chakrar Watershed (CW) is $112.9 \mathrm{~km}$ while the data of 9 sub-watersheds (SW) is expressed in Table 2. Among the sub-watersheds SW 3 has the largest value i.e. $46.39 \mathrm{~km}$ covering larger basin area of $65 \mathrm{~km}^{2}$ while SW1 covering smallest perimeter of $11.95 \mathrm{~km}$ and attain an area of $7.79 \mathrm{~km}^{2}$ of all. Sub-watersheds are 


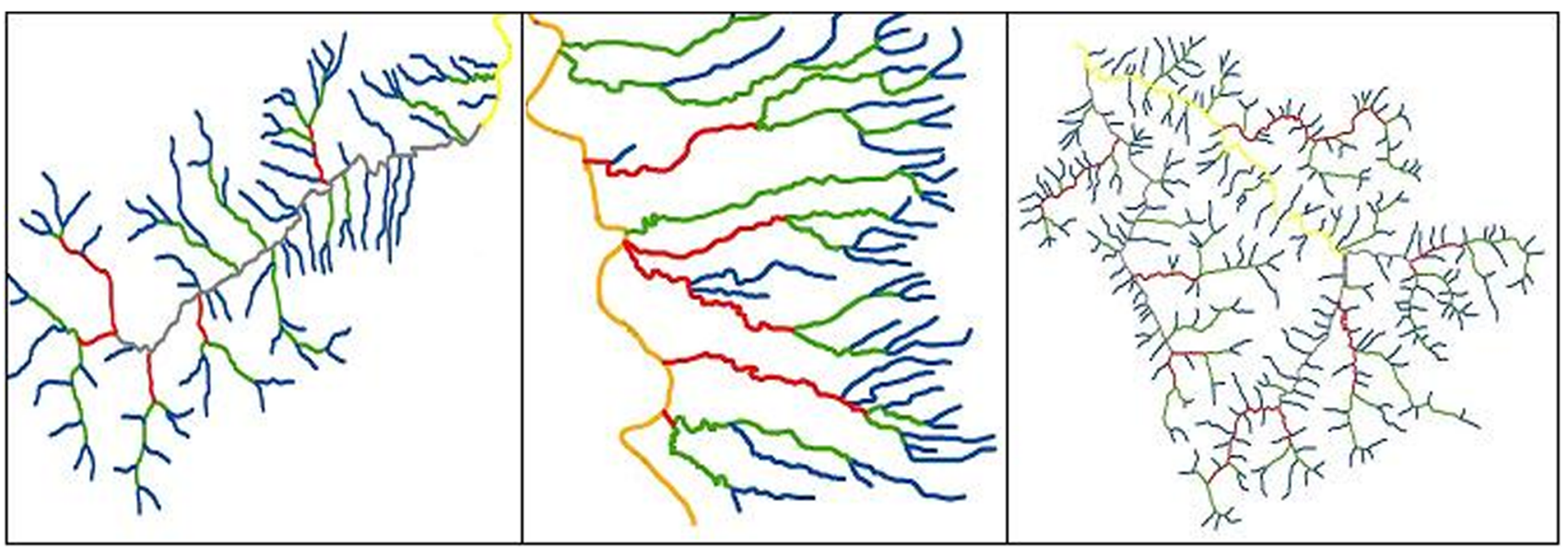

Fig. 2 Drainage pattern of Chakrar watershed. a Dendritic type, b parallel type, $\mathbf{c}$ trellis type

elongated to semi-circular because perimeter is increasing as area increasing $(r=0.99)$ but reverse in SW1.

\section{Basin length (Lb)}

The basin length of $\mathrm{CW}$ is $56.33 \mathrm{~km}$ and rest of $9 \mathrm{SW}$ is discussed in Table 3. All the sub-watersheds are longer ones except SW1 $(5.84 \mathrm{~km})$. It shows positive correlation ( $r=0.98$ ) with basin area tends to head-ward erosion. Basin length is defined as straight line distance from a basin mouth to the outlet point (Horton 1932).

\section{Stream order $(\mathrm{Nu})$}

Stream ordering is an important aspect for drainage basin analysis. It is defined as a measure of the position of a stream in the hierarchy of streams (Horton 1945; Strahler 1957; Leopold et al. 1964). Strahler (1964) proposed a method of ranking of streams. The smallest fingertip tributaries are designated as order 1 . Where the two firstorder channels join, a channel segment of 2 nd order is formed and so forth. The highest order stream carries discharge and sediment loads. It reveals about size of stream, runoff, drainage area and its extent is directly proportional to the size of watershed. Ordering of $9 \mathrm{SW}$ is tabulated in Table 2. It has been found that the study area is a 6 th order drainage basin having 1314 total streams, sprawl over $415 \mathrm{~km}^{2}$ (Fig. 3).

\section{Stream number (Nt)}

The number of streams of each order in a given watershed is known as stream number. Law of stream order (Horton 1945) describes that the number of streams of each order forms an inverse geometric sequence against stream order. Relationship between logarithm of number of streams against stream order shows a straight line with a deviation which indicates that the number of streams decreases as stream order increases and describes homogeneous subsurface material subjected to weathering and latter basin is characterized by lithologic and topographic variation (Nag and Lahiri 2011). The graph (Fig. 4) validates the Horton's law of stream number as the coefficient of correlation is -0.77 .

\section{Stream length (Lt)}

The mean and total stream length of each order is measured using GIS technique and tabulated in Table 2. It shows development of the stream segments and surface runoff characteristics. Streams having relatively smaller lengths indicate that the area is with high slopes. Longer stream lengths are indicative of flatter gradient. According to Strahler (1964), mean stream length describes the characteristic size of components of stream network. The mean stream length of a given order is less than the next higher order while total stream length is maximum in first order and decreases as the stream order increases. But in the case of mean stream length anomaly is found in SW3, SW4, SW7 and SW9 and in case of total stream length anomaly is found in SW1, SW7 and SW9. This type of variation may occur due to stream flow, rock types, slope and topography (Singh and Singh 1997; Vittala et al. 2004; Thomas et al. 2010). The regression line plotted on semi log graph (Fig. 5) which validates Horton's Law of stream length as the coefficient of correlation is 0.78 .

\section{Bifurcation ratio $(R b)$}

Bifurcation ratio is the ratio of the number of streams of any given order to the number of streams in the next higher order (Schumm 1956). It is a measure of degree of

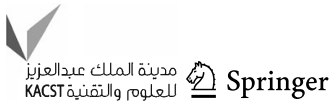


Table 2 Linear aspects of the CW and sub-watersheds

\begin{tabular}{|c|c|c|c|c|c|c|c|c|c|c|}
\hline Parameters & SW1 & SW2 & SW3 & SW4 & SW5 & SW6 & SW7 & SW8 & SW9 & $\mathrm{CW}$ \\
\hline Perimeter $(\mathrm{km})$ & 11.95 & 34.52 & 46.39 & 26.05 & 21.12 & 21.04 & 22.95 & 20 & 32.98 & 112.9 \\
\hline Basin Length & 5.84 & 16.25 & 19.67 & 11.08 & 8.95 & 9.87 & 11.85 & 9.24 & 15.36 & 56.33 \\
\hline \multicolumn{11}{|c|}{ Number of streams } \\
\hline N1 & 18 & 125 & 197 & 85 & 75 & 71 & 61 & 48 & 102 & 1016 \\
\hline $\mathrm{N} 2$ & 4 & 27 & 30 & 18 & 19 & 18 & 16 & 10 & 22 & 221 \\
\hline $\mathrm{N} 3$ & 2 & 9 & 7 & 5 & 4 & 5 & 3 & 3 & 4 & 55 \\
\hline N4 & 1 & 3 & 2 & 1 & 1 & 1 & 1 & 1 & 2 & 15 \\
\hline N5 & & 1 & 1 & & & & & & 1 & 6 \\
\hline N6 & & & & & & & & & & 1 \\
\hline NT & 25 & 165 & 237 & 109 & 99 & 95 & 81 & 62 & 131 & 1314 \\
\hline \multicolumn{11}{|c|}{ Total stream length } \\
\hline LT1 & 11.89 & 68.38 & 94.33 & 41.56 & 36.78 & 38.66 & 35.2 & 26.44 & 52.66 & 567.05 \\
\hline LT2 & 8.07 & 26.61 & 31.31 & 14.27 & 13.5 & 14.19 & 17.63 & 11.37 & 19.08 & 242.44 \\
\hline LT3 & 1.61 & 18.35 & 14.67 & 7.01 & 8.65 & 4.22 & 2.77 & 6.04 & 9.97 & 100.02 \\
\hline LT4 & 1.1 & 8.91 & 6.49 & 8.43 & 3.79 & 7.46 & 7.63 & 3.77 & 4.06 & 52.35 \\
\hline LT5 & & 3.28 & 10.32 & & & & & & 7.67 & 32.16 \\
\hline LT6 & & & & & & & & & & 25.77 \\
\hline Total & 22.67 & 125.53 & 157.12 & 71.27 & 62.72 & 64.53 & 63.23 & 47.62 & 93.44 & 1019.79 \\
\hline \multicolumn{11}{|c|}{ Mean steam length } \\
\hline Lm1 & 0.66 & 0.55 & 0.48 & 0.49 & 0.49 & 0.54 & 0.58 & 0.55 & 0.52 & 0.56 \\
\hline $\mathrm{Lm} 2$ & 2.02 & 0.99 & 1.04 & 0.79 & 0.71 & 0.79 & 1.10 & 1.14 & 0.87 & 1.10 \\
\hline Lm3 & 0.81 & 2.04 & 2.10 & 1.40 & 2.16 & 0.84 & 0.92 & 2.01 & 2.49 & 1.82 \\
\hline $\mathrm{Lm} 4$ & 1.10 & 2.97 & 3.25 & 8.43 & 3.79 & 7.46 & 7.63 & 3.77 & 2.03 & 3.49 \\
\hline Lm5 & & 3.28 & 10.32 & & & & & & 7.67 & 5.36 \\
\hline Lm6 & & & & & & & & & & 25.77 \\
\hline \multicolumn{11}{|l|}{ Bifurcation ratio } \\
\hline $\mathrm{Rb} 1-2$ & 4.50 & 4.63 & 6.57 & 4.72 & 3.95 & 3.94 & 3.81 & 4.80 & 4.64 & 4.60 \\
\hline $\mathrm{Rb} 2-3$ & 2 & 3 & 4.29 & 3.60 & 4.75 & 3.60 & 5.33 & 3.33 & 5.50 & 4.02 \\
\hline $\mathrm{Rb} 3-4$ & 2 & 3 & 3.50 & 5 & 4 & 5 & 3 & 3 & 2 & 3.67 \\
\hline $\mathrm{Rb} 4-5$ & & 3 & 2 & & & & & & 2 & 2.50 \\
\hline $\mathrm{Rb} 5-6$ & & & & & & & & & & 6 \\
\hline Mean $\mathrm{Rb}$ & 2.83 & 3.41 & 4.09 & 4.44 & 4.23 & 4.18 & 4.05 & 3.71 & 3.53 & 4.16 \\
\hline \multicolumn{11}{|c|}{ Stream length ratio } \\
\hline Rl 2-1 & 3.05 & 1.80 & 2.18 & 1.62 & 1.45 & 1.45 & 1.91 & 2.06 & 1.68 & 1.97 \\
\hline Rl 3-2 & 0.40 & 2.07 & 2.01 & 1.77 & 3.04 & 1.07 & 0.84 & 1.77 & 2.87 & 1.66 \\
\hline Rl 4-3 & 1.37 & 1.46 & 1.55 & 6.01 & 1.75 & 8.84 & 8.26 & 1.87 & 0.81 & 1.92 \\
\hline R1 5-4 & & 1.10 & 3.18 & & & & & & 3.78 & 1.54 \\
\hline Rl 6-5 & & & & & & & & & & 4.81 \\
\hline Mean & 1.61 & 1.61 & 2.23 & 3.13 & 2.08 & 3.79 & 3.67 & 1.90 & 2.29 & 2.38 \\
\hline \multicolumn{11}{|l|}{ Rho coefficient } \\
\hline Rho & 0.57 & 0.47 & 0.55 & 0.71 & 0.49 & 0.91 & 0.91 & 0.51 & 0.65 & 0.57 \\
\hline
\end{tabular}

distribution of stream network (Mesa 2006) and influences the landscape morphometry and control over the "peakedness" of the runoff (Chorley 1969). The Rb value ranges from 3.0 to 5.0 for networks formed on homogeneous rocks when the influences of geologic structures on the stream network is negligible (Strahler 1964; Verstappen 1995; Nag 1998; Vittala et al. 2004) and values higher than 10 where structural controls play dominant role with elongate basins (Mekel 1970; Chow et al. 1988). The Rb values reflect shape of basin (Verstappen 1983; Ghosh and 
Table 3 Areal aspects of the CW and sub-watersheds

\begin{tabular}{|c|c|c|c|c|c|c|c|c|c|c|}
\hline Parameters & SW1 & SW2 & SW3 & SW4 & SW5 & SW6 & SW7 & SW8 & SW9 & $\mathrm{CW}$ \\
\hline Area $\left(\mathrm{km}^{2}\right)$ & 7.79 & 49.91 & 65 & 29.78 & 24.29 & 23.2 & 24.38 & 19.06 & 39.48 & 415 \\
\hline Drainage density (Dd) & 2.91 & 2.52 & 2.42 & 2.39 & 2.58 & 2.78 & 2.59 & 2.50 & 2.37 & 2.46 \\
\hline Stream frequency $(\mathrm{Sf})$ & 3.21 & 3.31 & 3.65 & 3.66 & 4.08 & 4.09 & 3.32 & 3.25 & 3.32 & 3.17 \\
\hline Drainage texture (Dt) & 9.34 & 8.31 & 8.81 & 8.76 & 10.52 & 11.39 & 8.62 & 8.13 & 7.85 & 7.78 \\
\hline$L$ of OL flow (Lg) & 0.17 & 0.20 & 0.21 & 0.21 & 0.19 & 0.18 & 0.19 & 0.20 & 0.21 & 0.20 \\
\hline$C$ of channel M (C) & 0.34 & 0.40 & 0.41 & 0.42 & 0.39 & 0.36 & 0.39 & 0.40 & 0.42 & 0.41 \\
\hline Form factor (Ff) & 0.23 & 0.19 & 0.17 & 0.24 & 0.30 & 0.24 & 0.17 & 0.22 & 0.17 & 0.13 \\
\hline Circularity ratio (Rc) & 0.69 & 0.53 & 0.38 & 0.55 & 0.68 & 0.66 & 0.58 & 0.60 & 0.46 & 0.41 \\
\hline Elongation ratio $(\mathrm{Re})$ & 0.54 & 0.49 & 0.46 & 0.56 & 0.62 & 0.55 & 0.47 & 0.53 & 0.46 & 0.41 \\
\hline Shape index (Sw) & 4.38 & 5.29 & 5.95 & 4.12 & 3.30 & 4.20 & 5.76 & 4.48 & 5.98 & 7.65 \\
\hline
\end{tabular}

Chhibber 1984). Elongated basins have low $\mathrm{Rb}$ values while circular basins have high $\mathrm{Rb}$ values (Morisawa 1985). The mean $\mathrm{Rb}$ value of $\mathrm{CW}$ is 4.16 and value of 9 sub-watersheds varies from 2.83 to 4.44 . SW1 has lowest mean $\mathrm{Rb}$ value which shows high infiltration rate and rest of sub-watershed has higher $\mathrm{Rb}$ value ranges from 3.41 to 4.44 (Table 2) which shows high overland flow and discharge due to hilly nature of terrain.

\section{Stream length ratio $(R l)$}

Stream length ratio is the ratio of the mean length of the one order to the next lower order of the stream networks. The stream length ratio gives an idea about the relative permeability of the rock formation. Horton's law (1945) of stream length states that mean stream length segments of each of the successive orders of a basin tends to approximate a direct geomorphic series with stream length towards higher order of streams. The mean $\mathrm{Rl}$ of $\mathrm{CW}$ is 2.38 and varies for $9 \mathrm{SW}$ from 1.61 to 3.79 (Table 2). There is a variation in stream length ratio between streams of different order due to differences between slope and topography indicating the late youth stage of geomorphic development in the streams of the study area (Singh and Singh 1997; Vittala et al. 2004).

\section{Rho coefficient (Rho)}

Rho coefficient is defined as ratio of stream length ratio and bifurcation ratio (Horton 1945). Rho coefficient indicates storage capacity of drainage network. Rho value of $\mathrm{CW}$ is 0.57 and rest of $9 \mathrm{SW}$ is ranges from 0.47 to 0.91 . SW2 and SW5 have value of 0.47 and 0.49 while other SW has a value more than 0.50 indicating higher hydrologic storage during floods.

\section{Areal aspects}

Area

The CW has a catchment area of $415 \mathrm{~km}^{2}$. SW1 is the smallest of all $\left(7.79 \mathrm{~km}^{2}\right)$ whereas SW3 is the largest one among the 9 sub-watersheds.

\section{Drainage density $(D d)$}

Drainage density is the ratio of total stream length of all the orders per unit basin area (Horton 1945). Dd is a numerical measure of landscape dissection and runoff potential (Chorley 1969). It shows infiltration capacity of the land and vegetation cover of the catchment (Macka 2001). Dd influences the output of water and sediment from the catchment area (Ozdemir and Bird 2009) and erosion susceptibility (Anon 1988; Gregory and Walling 1973; Bates 1981). Dd of the drainage basin depends on climatic condition and vegetation (Moglen et al. 1998), landscape properties like soil and rock (Kelson and Wells 1989) and relief (Oguchi 1997). The drainage density indicates the groundwater potential of an area, due to its relation with surface runoff and permeability. Low drainage density generally results in the areas of permeable subsoil material, dense vegetation and low relief (Nag 1998). While high drainage density is the resultant of impermeable subsurface material, sparse vegetation and mountainous relief. Low drainage density leads to coarse drainage texture while high drainage density leads to fine drainage texture. The $\mathrm{CW}$ had a Dd value $2.46 \mathrm{~km} / \mathrm{km}^{2}$, fells in its medium category which indicates gentle to steep slope terrain, medium dense vegetation, and less permeable with medium precipitation. Value for 9 sub-watersheds is listed in Table 3. 
Fig. 3 Stream order in Chakrar watershed

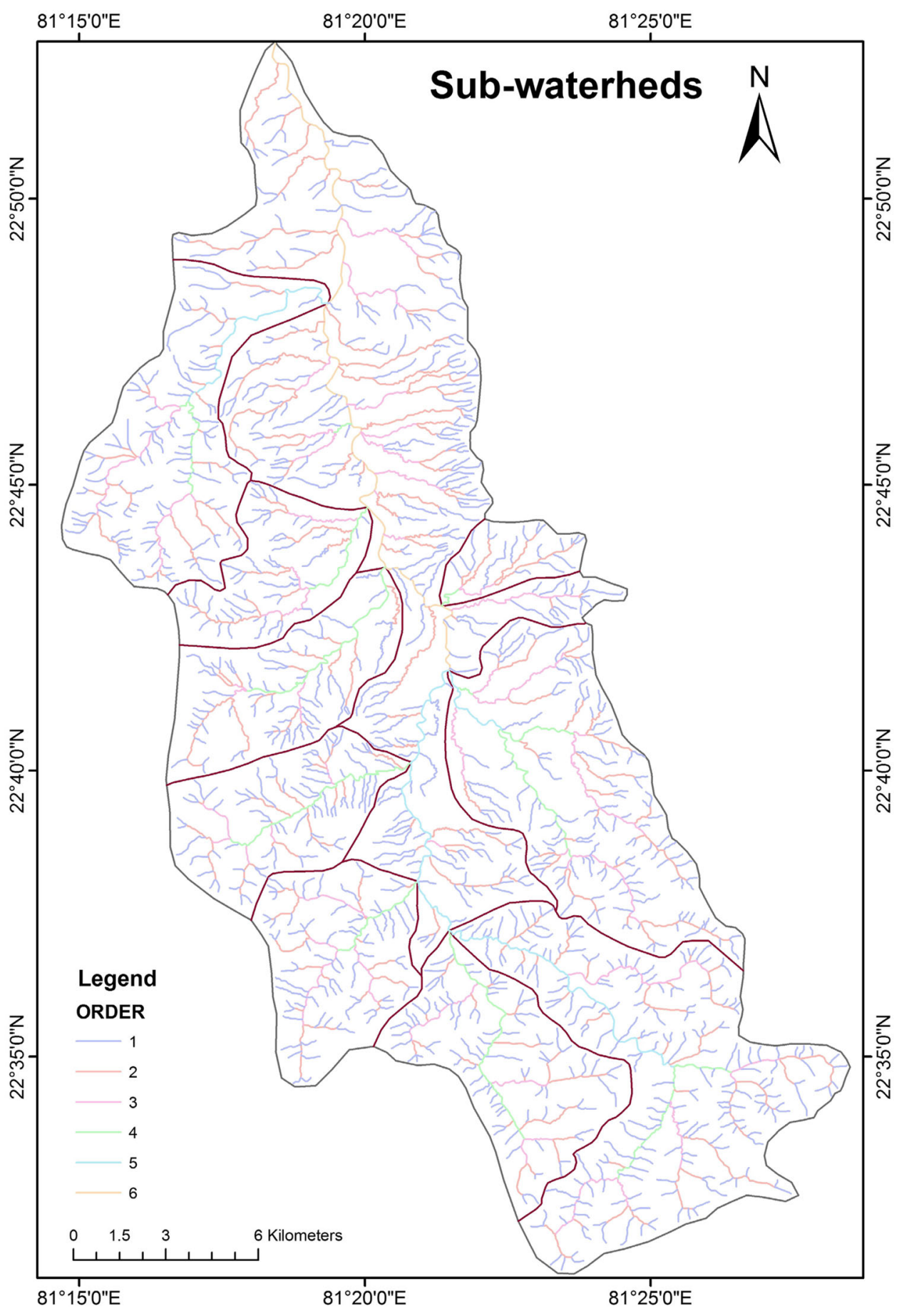

\section{Stream frequency $(S f)$}

Stream frequency of a basin is defined as the number of streams per unit area (Horton 1945). A higher stream frequency points to a larger surface runoff, steeper ground surface, impermeable subsurface sparse vegetation and high relief conditions. Low stream frequency indicates high permeable geology and low relief. The $\mathrm{Sf}$ of $\mathrm{CW}$ is 3.17 numbers per $\mathrm{km}^{2}$ while Fs of $9 \mathrm{SW}$ vary from 3.21 to 4.09 indicating poor runoff. Sf values of all the sub-watersheds have close correlation with Dd indicating the increase in stream population with respect to increase in drainage density.

\section{Drainage texture $(D t)$}

Drainage texture is the product of Dd and Sf and is a measure of relative channel spacing in a fluvial-dissected terrain, which is influenced by climate, rainfall, vegetation, 


\section{Stream Numbervs. Stream Order}

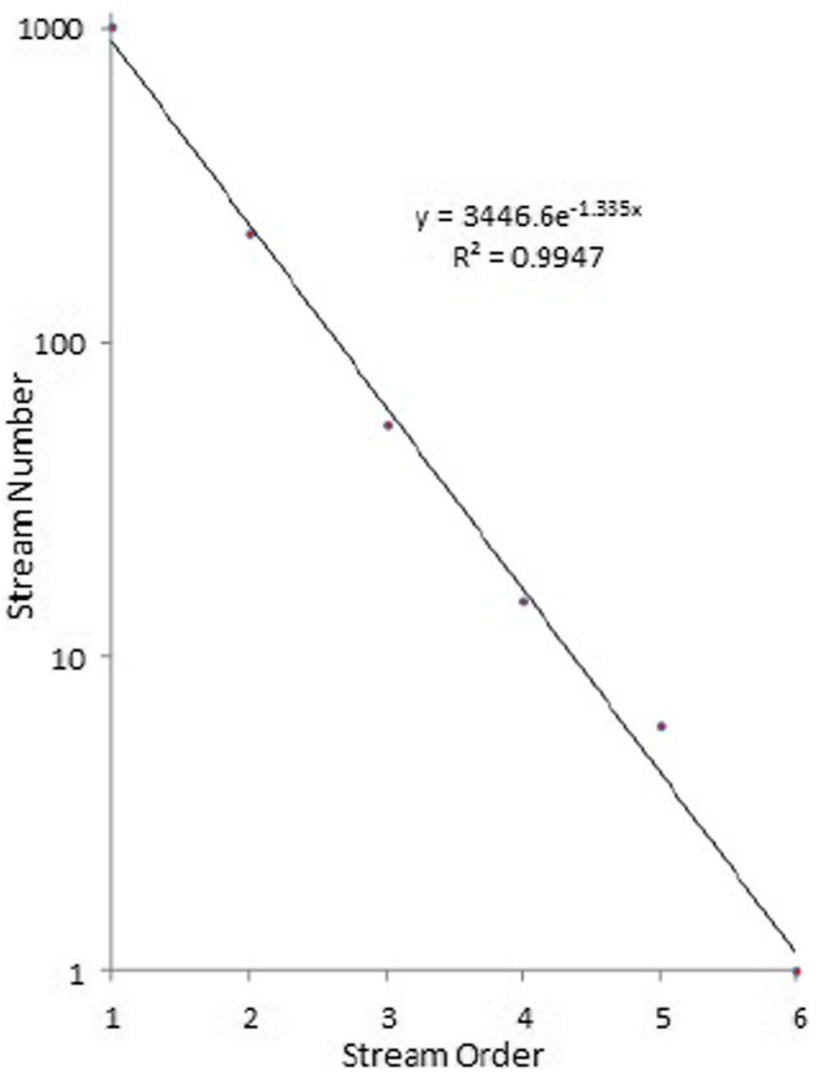

Fig. 4 Relation between stream order and stream number

lithology, soil type, infiltration capacity and stage of development (Smith 1950). Vegetation cover, its density and types also plays an important role in determining the drainage texture (Kale and Gupta 2001). The soft or weak rocks unprotected by vegetation produce a fine texture, whereas massive and resistant rocks cause coarse texture. Sparse vegetation of arid climate causes finer textures than those developed on similar rocks in a humid climate. The texture of a rock is commonly dependent upon vegetation type and climate (Dornkamp and King 1971). Drainage lines are numerous over impermeable areas than permeable areas. Horton (1945) recognized infiltration capacity as the single important factor which influences drainage texture and considered drainage texture which includes drainage density and stream frequency. Dt is categorized into five different classes based on Dd values viz; very course $(<2)$, course (2-4), moderate (4-6), fine (6-8) and very fine $(>8)$. The CW shows very fine texture, SW1, 8 and 9 shows course texture while rest of the SW show moderate texture.

\section{Length of overland flow $(\mathrm{Lg})$}

Length of overland flow is described as half of reciprocal of drainage density. It is the length of water over the
Cumulative Mean Stream Lengthvs. Stream Order

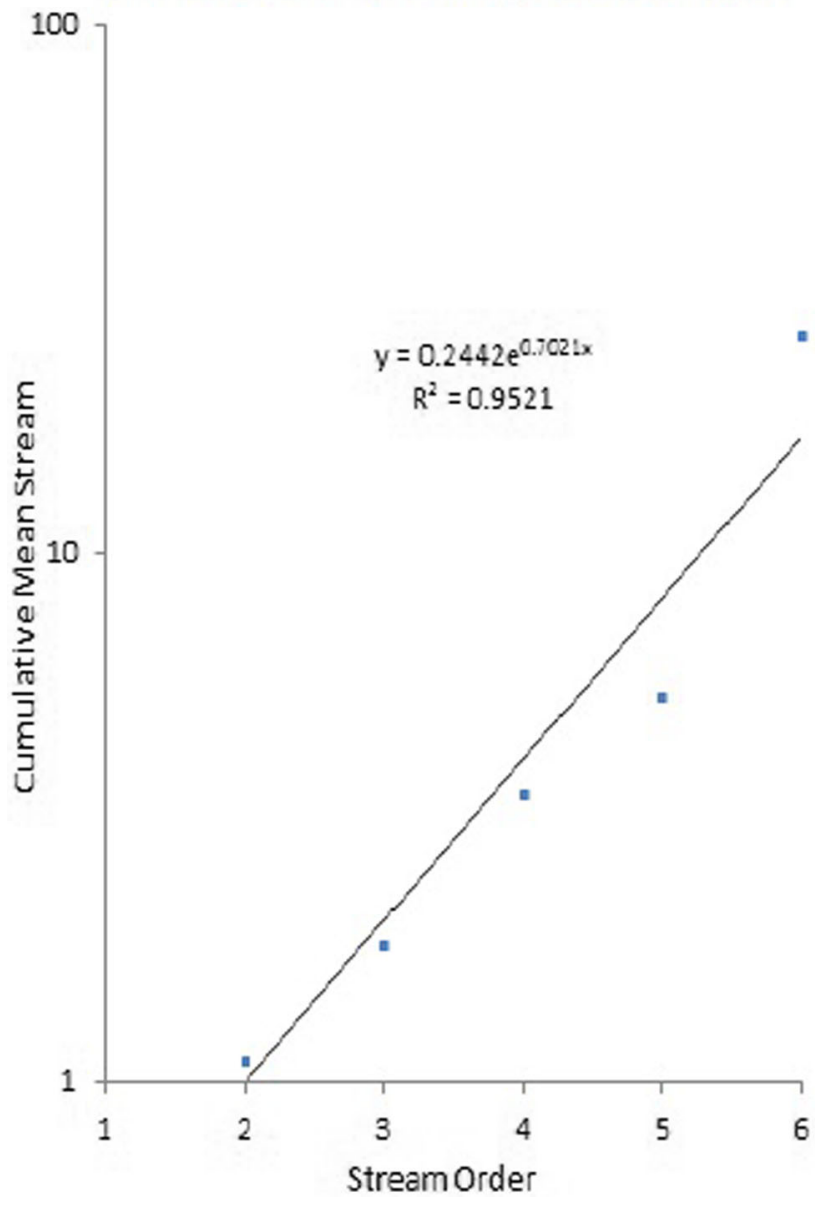

Fig. 5 Relation between stream order and mean stream length

ground before it gets concentrated into main stream which effect hydrologic and physiographic development of drainage basin (Horton 1945). According to Suresh (2000), when rainfall intensity exceeds soil infiltration capacity, the excess water flows over the land surface as overland flow. This factor depends on the rock type, permeability, climatic regime, vegetation cover and relief as well as duration of erosion (Schumm 1956). The CW has $\mathrm{Lg}$ value of 0.20 while all the sub-watersheds value range 0.17 to 0.21 , as shown in Table 3, indicates the influence of high structural disturbance, low permeability, steep to very steep slopes and high surface runoff. The $\mathrm{CW}$ and sub-watersheds show a well-developed stream network and mature geomorphic stage.

\section{Constant of channel maintenance $(C c)$}

This parameter indicates the requirement of units of watershed surface to bear one unit of channel length. Schumm (1956) has used the inverse of the drainage density having the dimension of length as a property termed

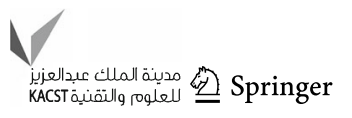


constant of channel maintenance. The drainage basins having higher values of this parameter, there will be lower value of drainage density. The computed value is given in Table 3. The value reports a $\mathrm{Cc}$ value of $\mathrm{CW}$ is 0.41 and the $\mathrm{Cc}$ value of 9 sub-watersheds varies from 0.34 to 0.42 . Higher value of $\mathrm{Cc}$ reveals strong control of lithology with a surface of high permeability and indicates relatively higher infiltration rates, moderate surface runoff, less dissection and watershed is not influenced by structural parameters.

\section{Basin configuration}

Floods are formed and move depends on basin shape. It is known that floods are formed and travel more rapidly in a round basin than in an elongated one and moreover that floods in basins of the former type are stronger and have a higher velocity and thus greater erosion and transport capacities. As elongated shape favor a diminution of floods because tributaries flow into the main stream at greater intervals of time and space.

\section{Form factor ( Ff)}

Form factor is a dimensionless ratio of the area $(A)$ of a drainage basin to the square of its maximum length $(\mathrm{Lb})$ (Horton 1932). Basin shape may be indexed by simple dimensionless ratios of the basic measurements area, perimeter and length (Singh 1998). Form factor is an indicator for flood formation and move, degree of erosion and transport capacities of sediment load in a watershed. The Ff of $\mathrm{CW}$ is 0.13 and that of 9 sub-watersheds (Table 3) varies from 0.17 to 0.24 . The value of Ff varies from 0 (highly elongated shape) to unity i.e.; 1 (perfect circular shape). Main watershed and sub-watersheds shows a lower value of $\mathrm{Ff}$ which implies more elongated basin with flatter peak of low flow for longer duration, lower erosion and sediment transport capacities and favors a diminution of floods because streams flow into the main stream at greater time intervals and space which leads to ground water percolation.

\section{Circularity ratio $(R c)$}

According to Miller (1953), circularity ratio is the ratio of the basin area $(A)$ and the area of a circle with the same perimeter as that of the basin. The value of ratio is equal to unity when the basin shape is a perfect circle and is range 0.4-0.5 when the basin shape is strongly elongated and highly permeable homogeneous geologic materials. The circularity ratio is influenced by the slope, relief geologic structure of the basin and landuse/landcover. The $\mathrm{CW}$ has a Rc value 0.41 , whereas in 9 sub-watershed, the value range between 0.38 and 0.69 .
Low Rc value implies elongated basin shape while high Rc value indicates near circular. Rc value has a positive correlation $(r=0.76)$ between form factor.

\section{Elongation ratio $(\mathrm{Re})$}

Elongation ratio is defined as the ratio of diameter of a circle of the same area as the basin to the maximum basin length (Schumm 1956). It is an important index for the analysis of basin shape. Analysis of elongation ratio indicates that the areas with higher elongation ratio values have high infiltration capacity and low runoff. A circular basin is more efficient in the discharge of runoff than an elongated basin (Singh and Singh, 1997). Strahler (1964) classified elongation ratio as follows: circular $(0.9-1.0)$, oval (0.8-0.9), less elongated (0.7-0.8), elongated (0.5-0.7) and more elongated $(<0.5)$. The Re of $\mathrm{CW}$ is 0.41 and values of 9 sub-watershed is varies from 0.46 to 0.62 . The Re values indicate elongated basin shape with high relief and gentle to steep slope.

\section{Shape index $(S w)$}

Shape index is a dimensionless entity and is a reciprocal of form factor. The CW has a value of 7.65 and rest of 9 subwatersheds range 3.30-5.98. Higher the shape index shows basin elongation and weak flood discharge period.

\section{Relief aspects}

\section{Basin relief ( $R)$}

According to Rao et al. (2011), calculation of basin relief to show spatial variation is predominant. Basin relief is the maximum vertical distance between the lowest and the highest point of a basin. Basin relief is responsible for the stream gradient and influences flood pattern and sediment volume that can be transported (Hadley and Schumm 1961). It is an important factor in understanding denudation characteristics of the basin (Sreedevi et al. 2009). To define relief DEM is shown in Fig. 6. The $R$ value of CW is $0.32 \mathrm{~km}$ while rest of 9 sub-watersheds is described in Table 4 .

\section{Relief ratio $(R r)$}

Relief ratio is a dimensionless ratio of basin relief and basin length and effective measure of gradient aspects of the watershed (Schumm 1956). It shows overall steepness of a drainage basin and is an indicator of the intensity of erosion processes operating on slopes of the basin (Javed et al. 2009). The Rr value of $\mathrm{CW}$ is 0.01 while values of 9 SW are given in Table 4. Values are relatively low $(<0.1)$ suggesting gentle slope. 


\section{Ruggedness number (Rn)}

To combine the qualities of slope steepness and length, a dimensionless ruggedness number is defined as the product of basin relief and drainage density (Strahler 1958). It is a measure of surface unevenness (Selvan et al. 2011). The $\mathrm{Rn}$ value of $\mathrm{CW}$ is 0.79 and rest of 9 sub-watersheds is provided in Table 4. The $\mathrm{Rn}$ value is relatively low which suggests less prone to soil erosion and have intrinsic structural complexity in association with relief and drainage density (Paretha and Paretha 2011).

\section{Dissection index (Di)}

Dissection index is determined for understanding morphometry, physiographic attribute and magnitude of dissection of terrain (Schumm 1956; Singh 2000; Singh and Dubey 1994). Dissection index is the ratio between actual

Fig. 6 Digital elevation model

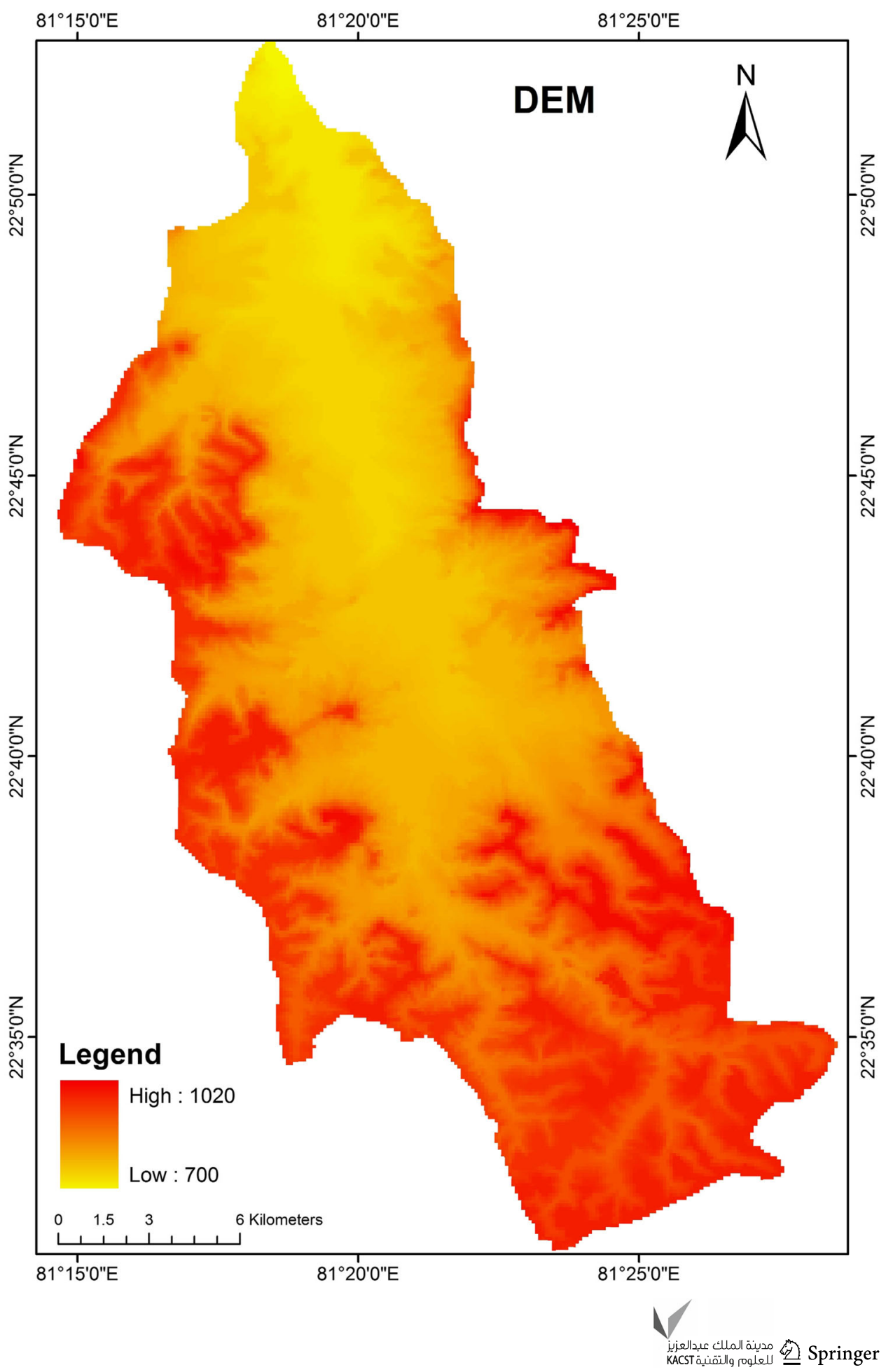


Table 4 Relief aspects of the CW and sub-watersheds

\begin{tabular}{|c|c|c|c|c|c|c|c|c|c|c|}
\hline Parameters & SW1 & SW2 & SW3 & SW4 & SW5 & SW6 & SW7 & SW8 & SW9 & $\mathrm{CW}$ \\
\hline Basin relief ( $\mathrm{R}$ in $\mathrm{m}$ ) & 260 & 240 & 180 & 180 & 180 & 220 & 230 & 260 & 260 & 320 \\
\hline Relief ratio $(\mathrm{Rr})$ & 0.04 & 0.01 & 0.01 & 0.02 & 0.02 & 0.02 & 0.02 & 0.03 & 0.02 & 0.01 \\
\hline Ruggedness No. (Rn) & 0.76 & 0.60 & 0.44 & 0.43 & 0.46 & 0.61 & 0.60 & 0.65 & 0.62 & 0.79 \\
\hline Dissection index (Di) & 0.26 & 0.24 & 0.18 & 0.19 & 0.19 & 0.23 & 0.24 & 0.27 & 0.27 & 0.33 \\
\hline Elevation at source (Es) & 1014 & 981 & 978 & 953 & 960 & 960 & 977 & 980 & 961 & 957 \\
\hline Elevation at mouth (Em) & 760 & 762 & 805 & 805 & 799 & 780 & 746 & 745 & 740 & 680 \\
\hline Gradient ratio $(\mathrm{Rg})$ & 0.04 & 0.01 & 0.01 & 0.01 & 0.02 & 0.02 & 0.02 & 0.03 & 0.01 & 0.005 \\
\hline Melton Rn & 0.09 & 0.03 & 0.02 & 0.03 & 0.04 & 0.05 & 0.05 & 0.06 & 0.04 & 0.02 \\
\hline
\end{tabular}

dissection made by the rivers and potential up to base levels (Pal et al. 2012). Di value of CW is 0.33 while 9 subwatersheds show values $0.18-0.27$. Lower value of $\mathrm{Di}$ implies old stage (Deen 1982) of basin and less degree of dissection.

\section{Gradient ratio $(R g)$}

Gradient ratio suggests channel slope from which runoff volume could be evaluated (Sreedevi et al. 2009). Rg values are tabulated in Table 4. Low $\mathrm{Rg}$ values show moderate relief terrain and main stream flow through plateau.

\section{Melton ruggedness number (MRn)}

According to Melton (1965), Melton Ruggedness number is a slope index that provides specialized representation of relief ruggedness within the watershed. The $\mathrm{CW}$ has MRn value 0.02 and 9 sub-watersheds range 0.02-0.09 which is a low value indicating a normal flow in main stream without more debris flow.

\section{Conclusion}

River basin is an important geomorphological unit which reflects topographic and hydrological unity. River basin characterization of Chakrar watershed and its sub-watershed revealed the importance of morphometric analysis in terrain depiction and basin evolution. GIS technique provided high accuracy in mapping and measurement of morphometric analysis. The analysis presents well developed drainage network and mature geomorphic stage in the watershed. The Dd value indicates moderate slope terrain with sparse to dense vegetation, higher infiltration rate, moderate surface runoff and less dissection. The watershed and its sub-watersheds are elongated in shape having less prone to flood, lower erosion and sediment transport capacities. Thus, morphometric parameters provide relevant information about terrain characteristics and hydrological behavior of the watershed. It is concluded that the integration of morphometric analysis with watershed assessment methods would be beneficial in watershed management plan.

Acknowledgments Author is thankful to Department of Remote Sensing and GIS, MGCGV Chitrakoot for providing the lab facility for the present study.

Open Access This article is distributed under the terms of the Creative Commons Attribution 4.0 International License (http:// creativecommons.org/licenses/by/4.0/), which permits unrestricted use, distribution, and reproduction in any medium, provided you give appropriate credit to the original author(s) and the source, provide a link to the Creative Commons license, and indicate if changes were made.

\section{References}

Agarwal CS (1998) Study of drainage pattern through aerial data in Naugarh area of Varanasi district, UP. J Indian Soc Remote Sens 26:169-175

Anon (1988) Watershed Atlas of India. All India Soil and Landuse Survey. Govt. of India, New Delhi, p 56

Banerjee A, Singh P, Pratap K (2015) Morphometric evaluation of Swarnrekha watershed, Madhya Pradesh, India: an integrated GIS-based approach. Appl Water Sci. doi:10.1007/s13201-0150354-3

Bates N (1981) Valley shapes. In: Knap B (ed) Practical foundations of physical geography. George Allen \& Unwin, London, pp 25-29

Biswas S, Sudhakar S, Desai VR (1999) Prioritisation of subwatersheds based on morphometric analysis of drainage basin a remote sensing and GIS approach. J Indian Soc Remote Sens 27:155-166

Chorley RJ (1969) Introduction to physical hydrology. Methuen and Co., Ltd., Suffolk 211

Chow VT, Maidment D, Mays LW (1988) Applied hydrology. McGraw Hill, New York

Deen M (1982) Geomorphology and Land use: a Case Study of Mewat. Thesis (PhD). JNU, New Delhi

Diwakar J, Thakur JK (2012) Environmental system analysis for river pollution control. Water Air Soil Pollut. doi:10.1007/s11270$012-1102-z$ 
Dornkamp JC, King CAM (1971) Numerical analyses in geomorphology, an introduction. St. Martins Press, New York 72

Esper AMY (2008) Morphometric analysis of Colanguil river basin and flash flood hazard, San Juan, Argentina. Environ Geol 55:107-111

Frissel CA et al (1986) A hierarchical framework for stream habitat classification-viewing streams in a watershed context. Environ Manage 10:199-214

Ghosh DK, Chhibber IB (1984) Aid of photo interpretation in the identification of geomorphic and geologic features around Chamba-Dharmasala area, Himachal Pradesh. J Indian Soc Photo Interpret Remote Sens 12(1):55-64

Gregory KJ, Walling DE (1973) Drainage basin form and process-a geomorphological approach. Edward Arnold, London

Hadley RF, Schumm SA (1961) Sediment sources and drainage basin characteristics in upper Cheyenne River basin. US Geological Survey, USGS water supply paper, 1531-B

Horton RE (1932) Drainage basin characteristics. Trans Am Geophys Union 13:350-361

Horton RE (1945) Erosional development of streams and their drainage basins-hydrophysical approach to quantitative morphology. Geol Soc Am Bull 56(3):275-370

Javed A, Khanday MY, Ahmaed R (2009) Prioritization of Subwatersheds based on morphomeric and land-use analysis using remote sensing and GIS techniques. J Indian Soc Remote Sens 37:261-274

Kale VS, Gupta A (2001) Introduction to geomorphology. Academic (India) Publishers, New Delhi

Kelson KI, Wells SG (1989) Geologic influences on fluvial hydrology and bed load transport in small mountainous watersheds, northern New Mexico, USA. Earth Surf Process Landf 14:671-690

Krishnamurthy J, Srinivas G (1995) Role of geological and geomorphological factors in groundwater exploration: a study using IRS LISS data. Int J Remote Sens 16:2595-2618

Kumar R, Kumar S, Lohani AK, Nema RK, Singh RD (2000) Evaluation of geomorphological characteristics of a catchment using GIS. GIS India 9(3):13-17

Leopold LB, Wolman MG, Miller JP (1964) Fluvial processes in geomorphology. San Francisco and London, WH Freeman and Company

Lima CDS, Correa ACDB, Nascimento NRD (2011) Analysis of the morphometric parameters of the Rio Preto Basin, Serra Do Espinhaco (Minas Gerais, Brazil, São Paulo, UNESP). Geociências 30(1):105-112

Lotspeich FB, Platts WS (1982) An integrated land-aquatic classification system. North Am J Fish Manag 2:138-149

Macka Z (2001) Determination of texture of topography from large scale contour maps. Geografski Vestnik 73(2):53-62

Malik MI, Bhat MS, Kuchay NA (2011) Watershed based drainage morphometric analysis of Lidder catchment in Kashmir valley using geographical information system. Recent Res Sci Technol 3(4): $118-126$

Mekel JFM (1970) The use of aerial photographs in geological mapping. ITC Text Book Photo Interpret 8:1-169

Melton MA (1965) The geomorphic and paleoclimatic significance of alluvial deposits in Southern Arizona. J Geol 73:1-38

Mesa LM (2006) Morphometric analysis of a subtropical Andean basin (Tucuman, Argentina). Environ Geol 50:1235-1242

Miller VC (1953) A quantitative geomorphic study of drainage basin characteristics in the Clinch mountain area, Virginia and Tennessee. Columbia University, New York (3)

Moglen GE, Eltahir EA, Bras RL (1998) On the sensitivity of drainage density to climate change. Water Resour Res 34:855-862

Moore ID, Grayson RB, Ladson AR (1994) Digital terrain modelling. In: Beven KJ, Moore ID (eds) A review of hydrological, geomorphological and biologial application. Wiley, Chichester, p 249

Morisawa M (1985) Geomorphology texts books: rivers, forms and process. Chapter 5, Structural and lithological control

Nag SK (1998) Morphometric analysis using remote sensing techniques in the Chaka subwatershed, Purulia district, West Bengal. J Indian Soc Remote Sens 26(1\&2):69-76

Nag SK, Chakraborthy S (2003) Influence of rock types and structures in the development of drainage network in hard rock area. J Indian Soc Remote Sens 31(1):2535

Nag SK, Lahiri A (2011) Morphometric analysis of Dwarakeswar watershed, Bankura district, West Bengal, India, using spatial information technology. Int $\mathrm{J}$ Water Resour Environ Eng 3(10):212-219

Narendra K, Nageswara Rao K (2006) Morphometry of the Mehadrigedda watershed, Visakhapatnam district, Andhra Pradesh using GIS and resourcesat data. J Indian Soc Remote Sens 34:101-110

Oguchi T (1997) Drainage density and relative relief in humid steep mountains with frequent slope failure. Earth Surf Process Landf 22:107-120

Ozdemir H, Bird D (2009) Evaluation of morphometric parameters of drainage networks derived from topographic maps and DEM in point of floods. Environ Geol 56:1405-1415

Pal B, Samanta S, Pal DK (2012) Morphometric and hydrological analysis and mapping for Watut watershed using remote sensing and GIS techniques. Int J Adv Eng Technol 2(1):357-368

Paretha K, Paretha U (2011) Quantitative morphometric analysis of a watershed of Yamuna Basin, India using ASTER (DEM) data and GIS. Int J Geomat Geosci 2(1):248-269

Rao LAK, Ansari ZR, Yusuf A (2011) Morphometric analysis of drainage basin using remote sensing and GIS techniques: a case study of Etmadpur Tehsil, Agra District UP. Int J Res Chem Environ 1(2):36-45

Rekha VB, George AV, Rita M (2011) Morphometric analysis and micro-watershed prioritization of Peruvanthanam sub-watershed, the Manimala River Basin, Kerala, South India. Environ Res Eng Manage 3(57):6-14

Schumm SA (1956) Evolution of drainage systems and slopes in badlands at Perth Amboy, New Jersey. Geol Soc Am Bull 67:597-646

Selvan MT, Ahmad S, Rashid SM (2011) Analysis of the Geomorphometric parameters in high altitude Glacierised terrain using SRTM DEM data in Central Himalaya, India. ARPN J Sci Technol 1(1):22-27

Singh S (1998) Geomorphology. Prayag pustak bhawan, Allahabad

Singh S (2000) Geomorphology. Ed. Allahabad: Prayag Pustak Bhawan, pp 642

Singh P, Thakur JK et al (2011) Assessment of land use/land cover using Geospatial Techniques in a semi arid region of Madhya Pradesh, India. Geospatial Techniques for Managing Environmental Resources. Thakur, Singh, Prasad, Gossel, Heidelberg, Germany, Springer and Capital publication, pp 152-163

Singh S, Dubey A (1994) Geo environmental planning of watersheds in India. Chugh Publications, Allahabad, pp 28-69

Singh S, Singh MC (1997) Morphometric analysis of Kanhar river basin. National Geographical J. of India, (43), 1:31-43

Singh P, Thakur JK, Singh UC (2013) Morphometric analysis of Morar River Basin, Madhya Pradesh, India, using remote sensing and GIS techniques. Environ Earth Sci 68:1967-1977

Singh P, Gupta A, Singh M (2014) Hydrological Inferences from Watershed analysis for water resource management using remote sensing and GIS techniques. Egypt J Remote Sens Space Sci 17:111-121

Smith KG (1950) Standards for grading texture of erosional topography. Am J Sci 248:655-668 
Soni SK, Tripathi S, Maurya AK (2013) GIS based morphometric characterization of mini-watershed-Rachhar Nala of Anuppur District Madhya Pradesh. Int J Adv Technol Eng Res 3(3):32-38

Sreedevi PD, Owais S, Khan HH, Ahmed S (2009) Morphometric analysis of a watershed of South India using SRTM data and GIS. J Geol Soc India 73(4):543-552

Sreedevi PD, Sreekanth PD, Khan HH, Ahmed S (2013) Drainage morphometry and its influence on hydrology in an semi arid region: using SRTM data and GIS. Environ Earth Sci 70(2):839-848

Srivastava VK, Mitra D (1995) Study of drainage pattern of Raniganj Coalfield (Burdwan District) as observed on Landsat TM/IRS LISS II imagery. J Indian Soc Remote Sens 23:225-235

Strahler AN (1957) Quantitative analysis of watershed geomorphology. Trans Am Geophy Union 38:913-920

Strahler AN (1958) Dimensional analysis applied to fluvially eroded landforms. Geol Soc Am Bull 69:279-300

Strahler AN (1964) Quantitative geomorphology of drainage basin and channel networks. In: Chow VT (ed) Handbook of applied hydrology. McGraw Hill Book, New York, pp 4-76

Suresh R (2000) Soil and water conservation engineering, 3rd edn. 24. Watershed-concept and management, pp 785-813

Thakur JK, Thakur RK, Ramanathan A, Kumar M, Singh SK (2011) Arsenic contamination of groundwater in Nepal-an overview. Water 3(1):1-20
Thomas J, Joseph S, Thrivikramaji KP (2010) Morphometric aspects of a small tropical mountain river system, the southern Western Ghats, India. Int J Digital Earth 3(2):135-156

Tripathi S, Soni SK, Maurya AK (2013) Morphometric characterization and prioritization of sub-watershed of Seoni River in Madhya Pradesh through remote sensing and GIS technique. Int J Remote Sens Geosci 2(3):46-54

Verstappen HT (1983) Applied geomorphology-geomorphological surveys for environmental development. Elsevier, New York, pp 57-83

Verstappen HT (1995) Aerospace technology and natural disaster reduction. In: Singh RP, Furrer R (eds) Natural hazards: monitoring and assessment using remote sensing technique. Pergamon Press, Oxford, pp 3-15

Vijith H, Satheesh R (2006) GIS based morphometric analysis of two major upland sub-watersheds of Meenachil river in Kerala. J Indian Soc Remote Sens 34(2):181-185

Vittala S, Govindaiah S, Honne GH (2004) Morphometric analysis of sub-watersheds in the Pavagada area of Tumkur district, South India using remote sensing and GIS techniques. J Indian Soc Remote Sens 32(4):351-362 